\title{
Marinobacterium lutimaris sp. nov., isolated from a tidal flat
}

Correspondence

Che Ok Jeon

cojeon@cau.ac.kr

\author{
Jeong Myeong Kim, Se Hee Lee, Ji Young Jung and Che Ok Jeon \\ Department of Life Science, Chung-Ang University, Seoul 156-756, Republic of Korea
}

Vast tidal flats, known as getbol, are found along the Yellow Sea coast of the Korean peninsula. These habitats alternately undergo flooding with seawater and exposure to the atmosphere. Getbols provide valuable areas for microorganisms and marine animals and play an important role in the restoration of human-impacted coastal ecosystems. In the past few years, numerous microbial species have been isolated from the getbols of the Yellow Sea (Yi \& Chun, 2004a, b, c; Baik et al., 2005; Kim et al., 2008a; Yoon et al., 2008, 2009). The genus Marinobacterium, a member of the Gammaproteobacteria, was proposed by González et al. (1997) with the description of Marinobacterium georgiense, and many Marinobacterium species have been isolated from marine sediments (Chang et al., 2007; Kim et al., 2007, 2009a, b; Huo et al., 2009). At the time of writing, the genus Marinobacterium comprises nine recognized species. In the course of investigations into the microbial communities inhabiting tidal flats of South Korea, a novel, moderately halophilic, Marinobacteriumlike bacterium, designated strain $\mathrm{AN}^{\mathrm{T}}$, was isolated from a tidal flat of the Yellow Sea. Based on data from the present polyphasic study, strain $\mathrm{AN}^{\mathrm{T}}$ is considered to represent a novel species of the genus Marinobacterium.

Strain $\mathrm{AN}^{\mathrm{T}}$ was isolated from getbol of Taean in South Korea by using a modification of the procedure described by Kim et al. (2008b). Briefly, the sediment was dispersed

The GenBank/EMBL/DDBJ accession number for the 16S rRNA gene sequence of strain $\mathrm{ANO}^{\top}$ is FJ230839.

A transmission electron micrograph of a cell of strain $\mathrm{AN}^{\top}$ is available as supplementary material with the online version of this paper. in $0.9 \%(\mathrm{w} / \mathrm{v})$ saline. The resultant suspension was serially diluted in 10-fold steps by the addition of $1 \mathrm{ml}$ of the previous dilution to $9 \mathrm{ml}$ saline, and $0.1-\mathrm{ml}$ aliquots from each diluted suspension were spread on marine agar 2216 (MA; Difco) plates. The plates were then incubated under aerobic conditions at $25{ }^{\circ} \mathrm{C}$ for 5 days. Colonies were selected randomly and crude lysates containing genomic DNA from colonies were prepared by boiling a small amount of cell material in $100 \mu \mathrm{l}$ of $5 \%$ Chelex 100 solution (Bio-Rad) for $10 \mathrm{~min}$. The supernatant was prepared by centrifugation at $15000 \mathrm{~g}$ for $10 \mathrm{~min}$, and PCR amplification of $16 S$ rRNA genes from the crude lysates was performed by using the universal primers described by Lu et al. (2006). The amplicons were doubledigested with restriction enzymes HaeIII and HhaI. Restriction fragment length polymorphism (RFLP) patterns were analysed on $2.5 \%$ MetaPhore agarose (BioWhittaker) gels; colonies were grouped according to their RFLP patterns and representative PCR products containing distinct RFLP patterns were sequenced. The resulting 16S rRNA gene sequences were analysed by using the BLAST program (http://www.ncbi.nlm.nih.gov/BLAST/) within the GenBank database. From this analysis, a novel Marinobacterium-like strain, $\mathrm{AN}^{\mathrm{T}}{ }^{\mathrm{T}}$, was selected for further phenotypic and phylogenetic analysis. The strain was routinely grown aerobically on $\mathrm{MA}$ at $30{ }^{\circ} \mathrm{C}$ for 3 days, except where indicated otherwise. The strain was stored at $-80{ }^{\circ} \mathrm{C}$ in marine broth (Difco) supplemented with $10 \%$ $(\mathrm{v} / \mathrm{v})$ glycerol.

The 16S rRNA gene sequence (1427 nt) of strain $\mathrm{AN} 9^{\mathrm{T}}$ was checked manually for quality and gaps. Sequence similarity 
values between the new isolate and the type strains of related bacteria were evaluated by using the Nucleotide Similarity Search program (http://147.47.212.35:8080; Chun et al., 2007) and the sequences were aligned by using the CLUSTAL W software program (Thompson et al., 1994). Phylogenetic trees were constructed by using the neighbour-joining, maximum-likelihood and maximumparsimony algorithms available in the PHYLIP program package, version 3.6 (Felsenstein, 2002). The resulting tree topologies were evaluated by bootstrap analysis based on 1000 resampled datasets with the PHYLIP package.

Phylogenetic analysis based on 16S rRNA gene sequences indicated that strain $\mathrm{AN}^{\mathrm{T}}$ formed a tight phyletic lineage with Marinobacterium litorale $\mathrm{IMCC} 1877^{\mathrm{T}}$ within the genus Marinobacterium with $100 \%$ bootstrap support (Fig. 1). The overall topologies of the maximum-likelihood and maximum-parsimony trees were essentially the same as that of the neighbour-joining tree (Fig. 1). Comparative $16 \mathrm{~S}$ rRNA gene sequence analysis showed that strain $\mathrm{AN}^{\mathrm{T}}$ was related most closely to $M$. litorale $\mathrm{IMCC} 1877^{\mathrm{T}}(96.8 \%$ similarity); levels of $16 \mathrm{~S}$ rRNA gene sequence similarity to the type strains of other Marinobacterium species were less than $94.2 \%$.

Growth of strain $\mathrm{AN} 9^{\mathrm{T}}$ at different temperatures and $\mathrm{pH}$ was examined on MA at $5-45{ }^{\circ} \mathrm{C}$ at $5{ }^{\circ} \mathrm{C}$ intervals and in marine broth adjusted to $\mathrm{pH} 5.0-10.0$ at $0.5 \mathrm{pH}$ unit intervals. The $\mathrm{pH}$ was adjusted prior to sterilization by the addition of $\mathrm{HCl}$ or $\mathrm{NaOH}$ and was measured again after sterilization. Gram staining was performed by using the bioMérieux Gram stain kit according to the manufacturer's instructions. Cell morphology and the presence of flagella

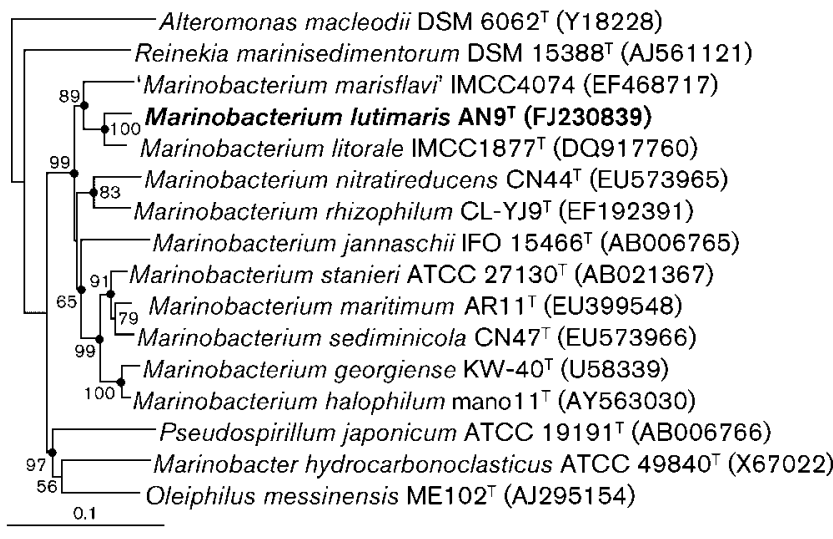

Fig. 1. Neighbour-joining tree based on 16S rRNA gene sequences showing the phylogenetic position of strain $A N 9^{\top}$ among related taxa. Bootstrap values are shown at nodes as percentages of 1000 replicates; only values $>50 \%$ are shown. Filled circles indicate that the corresponding nodes were also recovered in trees generated with the maximum-likelihood and maximum-parsimony algorithms. Alteromonas macleodii DSM $6062^{\top}$ was used as an outgroup. Bar, 0.1 changes per nucleotide position. were studied via phase-contrast microscopy and transmission electron microscopy (JEM-1010; JEOL) with 2-dayold cells grown on MA, as described by Jeon et al. (2004). Requirement for and tolerance of $\mathrm{NaCl}$ were determined in nutrient broth (NB; Difco) (3.0 g beef extract and $5.0 \mathrm{~g}$ peptone per litre distilled water) supplemented with modified artificial seawater [ASW; per litre distilled water: $0-15 \% \quad(\mathrm{w} / \mathrm{v}) \quad \mathrm{NaCl}$ at $0.5 \%$ intervals, $5.94 \mathrm{~g}$ $\mathrm{MgSO}_{4} \cdot 7 \mathrm{H}_{2} \mathrm{O}, 4.53 \mathrm{~g} \mathrm{MgCl}_{2} \cdot 6 \mathrm{H}_{2} \mathrm{O}, 0.64 \mathrm{~g} \mathrm{KCl}$ and $1.3 \mathrm{~g} \mathrm{CaCl}_{2}$ ] (Kahng et al., 2009). Oxidase activity was tested based on oxidation of $1 \%(\mathrm{w} / \mathrm{v})$ tetramethyl- $p$ phenylenediamine (Merck), and catalase activity was evaluated based on the production of oxygen bubbles in $3 \%(\mathrm{v} / \mathrm{v})$ aqueous hydrogen peroxide solution (Smibert \& Krieg, 1994). Nitrate reduction was assessed according to the method of Lányí (1987) and acid production from carbohydrates was tested as described by Leifson (1963). Antibiotic susceptibility tests were performed in duplicate by using filter-paper discs (diameter, $8 \mathrm{~mm}$ ) containing the following antibiotics: ampicillin $(10 \mu \mathrm{g})$, polymyxin $\mathrm{B}$ $(100 \mathrm{U})$, streptomycin $(50 \mu \mathrm{g})$, penicillin $\mathrm{G}$ (10 IU), gentamicin $(30 \mu \mathrm{g})$, chloramphenicol $(100 \mu \mathrm{g})$, tetracycline $(30 \mu \mathrm{g})$, kanamycin $(30 \mu \mathrm{g})$, lincomycin $(15 \mu \mathrm{g})$, oleandomycin $(15 \mu \mathrm{g})$, carbenicillin $(100 \mu \mathrm{g})$ and novobiocin $(50 \mu \mathrm{g})$. Additional enzyme activities and biochemical characteristics were determined by using API ZYM and API 20NE kits (bioMérieux) and utilization or oxidation of carbon sources was determined by using the GN MicroPlate system (Biolog) according to the instructions of the manufacturers. Growth was assessed on MA under anaerobic (with $4-10 \% \mathrm{CO}_{2}$ ) conditions by using the GasPak Plus system (BBL) at $30{ }^{\circ} \mathrm{C}$ for 15 days.

When tested on MA, growth of strain $\mathrm{AN}^{\mathrm{T}}$ was observed at $\quad 15-40{ }^{\circ} \mathrm{C}$ (optimum, $25-30{ }^{\circ} \mathrm{C}$ ), at pH 6.0-8.0 (optimum, $\mathrm{pH}$ 6.5-7.5) and in the presence of 1-10.0\% (w/v) $\mathrm{NaCl}$ (optimum, 2-5\%). Cells were Gram-stainingnegative, strictly aerobic, short motile rods $(0.6-0.8 \mu \mathrm{m}$ wide and 1.2-1.4 $\mu \mathrm{m}$ long) with a single polar flagellum (see Supplementary Fig. S1 in IJSEM Online). Phenotypic characteristics were in accordance with those of members of the genus Marinobacterium, but some characteristics allowed the differentiation of strain $\mathrm{AN}^{\mathrm{T}}$ from closely related Marinobacterium species (Table 1).

Isoprenoid quinones were analysed by HPLC (model LC20A; Shimadzu), as described by Komagata \& Suzuki (1987), with the chromatograph equipped with a diode array detector (SPD-M20A; Shimadzu) and a reversedphase column $(250 \times 4.6 \mathrm{~mm}$, Kromasil; Akzo Nobel). For analysis of fatty acid methyl esters, cells of strain $\mathrm{AN}^{\mathrm{T}}$ were harvested from MA plates after incubation at $30{ }^{\circ} \mathrm{C}$ for 3 days. Analysis was performed according to the instructions of the Microbial Identification System (MIDI; Microbial ID, Inc.). The DNA G $+\mathrm{C}$ content of strain $\mathrm{AN}^{\mathrm{T}}$ was determined by reversed-phase HPLC (GROM-SIL 100 ODS-2FE; GROM) according to the method of Tamaoka \& Komagata (1984). The major respiratory lipoquinone of strain $\mathrm{AN}^{\mathrm{T}}$ was ubiquinone 8 
Table 1. Differential phenotypic characteristics between strain $\mathrm{AN9}^{\top}$ and the type strains of Marinobacterium species

Strains: 1, AN9 ${ }^{\mathrm{T}} ; 2$, M. litorale $\mathrm{IMCC} 1877^{\mathrm{T}}$ (data from Kim et al., 2007); 3, M. georgiense KW-404 ${ }^{\mathrm{T}}$ (González et al., 1997); 4, M. nitratireducens $\mathrm{CN} 44^{\mathrm{T}}$ (Huo et al., 2009). All strains are positive for the following characteristics: motility with one polar flagellum, oxidase and catalase, growth at $40{ }^{\circ} \mathrm{C}$, sensitivity to streptomycin and utilization of propionic acid, citric acid and succinic acid. + , Positive; -, negative; w, weakly positive.

\begin{tabular}{|lcccc|}
\hline Characteristic & $\mathbf{1}$ & $\mathbf{2}$ & $\mathbf{3}$ & $\mathbf{4}$ \\
\hline Colony colour & (CW & BM & T & Y \\
Growth at/in: & & & & \\
$\quad 4{ }^{\circ} \mathrm{C}$ & - & - & + & - \\
$10 \% \mathrm{NaCl}$ & + & - & + & - \\
Hydrolysis of Tween 80 & + & W & + & - \\
Nitrate reduction & - & - & - & + \\
Gelatinase & - & - & + & - \\
Arginine dihydrolase & - & - & + & - \\
Carbon source utilization & & & & \\
$\quad$ D-Fructose & - & - & + & + \\
$\quad$ D-Mannose & - & - & + & - \\
Glycerol & - & - & + & + \\
L-Serine & + & + & - & + \\
D-Glucose & - & - & + & + \\
L-Aspartic acid & + & - & + & + \\
Sucrose & - & - & - & + \\
Formic acid & + & + & + & - \\
DNA G + C content (mol\%) & 58.0 & 60.7 & 54.9 & 62.5 \\
\end{tabular}

${ }^{\star} \mathrm{BM}$, Beige-milky; CW, creamy white; T, translucent; Y, yellow.

(Q-8). The predominant cellular fatty acids were $\mathrm{C}_{10: 0} 3$ $\mathrm{OH}(31.7 \%), \mathrm{C}_{18: 1} \omega 7 c(24.8 \%), \mathrm{C}_{16: 0}(14.7 \%)$, summed feature 3 (comprising $\mathrm{C}_{16: 1} \omega 7 c$ and/or iso- $\mathrm{C}_{15: 0} 2-\mathrm{OH}$, $10.7 \%), \mathrm{C}_{12: 0}(8.5 \%), \mathrm{C}_{12: 0} 2-\mathrm{OH}(7.0 \%)$ and $\mathrm{C}_{10: 0}$ $(2.5 \%)$. The DNA G $+\mathrm{C}$ content of strain $\mathrm{AN9}^{\mathrm{T}}$ was $58 \mathrm{~mol} \%$. The major lipoquinone, major fatty acids and DNA $\mathrm{G}+\mathrm{C}$ content were in accordance with those of members of the genus Marinobacterium (Chang et al., 2007; Huo et al., 2009; Kim et al., 2007, 2009a, b).

The physiological, biochemical and phylogenetic characteristics of strain $\mathrm{AN}^{\mathrm{T}}$ thus support its description as representing a novel species of the genus Marinobacterium, for which the name Marinobacterium lutimaris sp. nov. is proposed.

\section{Description of Marinobacterium Iutimaris sp. nov.}

Marinobacterium lutimaris (L. n. lutum mud; L. gen. n. maris of the sea; N.L. gen. n. lutimaris of sea mud).

Cells are Gram-staining-negative, motile rods, 0.6-0.8 $\mu \mathrm{m}$ wide and 1.2-1.4 $\mu \mathrm{m}$ long. Colonies on MA are creamy white, convex and round with entire margins. Growth occurs at $15-40{ }^{\circ} \mathrm{C}$ (optimum, $25-30{ }^{\circ} \mathrm{C}$ ) and at $\mathrm{pH} 6.0$ 8.0 (optimum, pH 6.5-7.5). Oxidase- and catalase-positive.
Negative for nitrate reduction, indole production, arginine dihydrolase, glucose fermentation, aesculin hydrolysis, gelatinase and $\beta$-galactosidase. Positive for alkaline phosphatase, esterase lipase (C8), leucine arylamidase, valine arylamidase, cystine arylamidase, trypsin, $\alpha$-chymotrypsin, acid phosphatase and $\alpha$-glucosidase activities but negative for lipase (C14), $\alpha$-galactosidase, $\beta$-galactosidase, $\beta$ glucuronidase, $N$-acetyl- $\beta$-glucosaminidase, $\alpha$-mannose and $\alpha$-fucosidase. Weak enzyme activities are observed for esterase (C4), $\beta$-glucosidase and naphthol-AS-BIphosphohydrolase (API ZYM). Positive for Biolog GN2 MicroPlate system substrates glycogen, Tweens 40 and 80, pyruvic acid methyl ester, succinic acid monomethyl ester, acetic acid, cis-aconitic acid, citric acid, formic acid, $\alpha$ hydroxybutyric acid, $\beta$-hydroxybutyric acid, $\gamma$-hydroxybutyric acid, $p$-hydroxyphenylacetic acid, $\alpha$-ketoglutaric acid, DL-lactic acid, malonic acid, propionic acid, quinic acid, succinic acid, bromosuccinic acid, succinamic acid, Lalaninamide, D- and L-alanine, L-alanyl glycine, L-asparagine, L-aspartic acid, L-glutamic acid, L-proline, Lpyroglutamic acid, L-serine and putrescine. Other organic substrates included in Biolog GN2 microplates are not utilized. The major isoprenoid quinone is $\mathrm{Q}-8$. The major cellular fatty acids are $\mathrm{C}_{10: 0} 3-\mathrm{OH}, \mathrm{C}_{18: 1} \omega 7 c$ and $\mathrm{C}_{16: 0}$. Resistant to carbenicillin, but sensitive to penicillin $G$, polymyxin B, streptomycin, gentamicin, tetracycline, neomycin, kanamycin, ampicillin, lincomycin, chloramphenicol and oleandomycin. The DNA G+C content of the type strain is $58.0 \mathrm{~mol} \%$ (HPLC).

The type strain, AN9 ${ }^{\mathrm{T}}$ (=KACC $13703^{\mathrm{T}}=$ DSM $22012^{\mathrm{T}}$ ), was isolated from a tidal flat of the Taean coast in South Korea.

\section{Acknowledgements}

This research was supported by a Chung-Ang University Research Scholarship Grant in 2008.

\section{References}

Baik, K. S., Seong, C. N., Kim, E. M., Yi, H., Bae, K. S. \& Chun, J. (2005). Hahella ganghwensis sp. nov., isolated from tidal flat sediment. Int J Syst Evol Microbiol 55, 681-684.

Chang, H. W., Nam, Y. D., Kwon, H. Y., Park, J. R., Lee, J. S., Yoon, J. H., An, K. G. \& Bae, J. W. (2007). Marinobacterium halophilum sp. nov., a marine bacterium isolated from the Yellow Sea. Int J Syst Evol Microbiol 57, 77-80.

Chun, J., Lee, J. H., Jung, Y., Kim, M., Kim, S., Kim, B. K. \& Lim, Y. W. (2007). EzTaxon: a web-based tool for the identification of prokaryotes based on $16 \mathrm{~S}$ ribosomal RNA gene sequences. Int J Syst Evol Microbiol 57, 2259-2261.

Felsenstein, J. (2002). PHYLIP (phylogeny inference package), version 3.6a. Distributed by the author. Department of Genome Sciences, University of Washington, Seattle, USA.

González, J. M., Mayer, F., Moran, M. A., Hodson, R. E. \& Whitman, W. B. (1997). Microbulbifer hydrolyticus gen. nov., sp. nov., and Marinobacterium georgiense gen. nov., sp. nov., two marine bacteria from a lignin-rich pulp mill waste enrichment community. Int J Syst Bacteriol 47, 369-376. 
Huo, Y. Y., Xu, X. W., Cao, Y., Wang, C. S., Zhu, X. F., Oren, A. \& Wu, M. (2009). Marinobacterium nitratireducens sp. nov. and Marinobacterium sediminicola sp. nov., isolated from marine sediment. Int J Syst Evol Microbiol 59, 1173-1178.

Jeon, C. O., Park, W., Ghiorse, W. C. \& Madsen, E. L. (2004). Polaromonas naphthalenivorans sp. nov., a naphthalene-degrading bacterium from naphthalene-contaminated sediment. Int J Syst Evol Microbiol 54, 93-97.

Kahng, H. Y., Chung, B. S., Lee, D. H., Jung, J. S., Park, J. H. \& Jeon, C. O. (2009). Cellulophaga tyrosinoxydans sp. nov., a tyrosinaseproducing bacterium isolated from seawater. Int J Syst Evol Microbiol 59, 654-657.

Kim, H., Choo, Y. J., Song, J., Lee, J. S., Lee, K. C. \& Cho, J. C. (2007), Marinobacterium litorale sp. nov., in the order Oceanospirillales. Int J Syst Evol Microbiol 57, 1659-1662.

Kim, Y. G., Jin, Y. A., Hwang, C. Y. \& Cho, B. C. (2008a). Marinobacterium rhizophilum sp. nov., isolated from the rhizosphere of the coastal tidal-flat plant Suaeda japonica. Int J Syst Evol Microbiol 58, 164-167.

Kim, J. M., Le, N. T., Chung, B. S., Park, J. H., Bae, J.-W., Madsen, E. L. \& Jeon, C. O. (2008b). Influence of soil components on the biodegradation of benzene, toluene, ethylbenzene, and o-, $\mathrm{m}-$, and p-xylenes by the newly isolated bacterium Pseudoxanthomonas spadix BD-a59. Appl Environ Microbiol 74, 7313-7320.

Kim, S.-J., Park, S.-J., Yoon, D.-N., Park, B.-J., Choi, B.-R., Lee, D.-H., Roh, Y. \& Rhee, S.-K. (2009a). Marinobacterium maritimum sp. nov., a marine bacterium isolated from Arctic sediment. Int J Syst Evol Microbiol 59, 3030-3034.

Kim, H., Oh, H. M., Yang, S. J., Lee, J. S., Hong, J. S. \& Cho, J. C. (2009b). Marinobacterium marisflavi sp. nov., isolated from a costal seawater. Curr Microbiol 58, 511-515.

Komagata, K. \& Suzuki, K. (1987). Lipid and cell-wall analysis in bacterial systematics. Methods Microbiol 19, 161-207.
Lányi, B. (1987). Classical and rapid identification methods for medically important bacteria. Methods Microbiol 19, 1-67.

Leifson, E. (1963). Determination of carbohydrate metabolism of marine bacteria. J Bacteriol 85, 1183-1184.

Lu, S., Park, M., Ro, H.-S., Lee, D. S., Park, W. \& Jeon, C. O. (2006). Analysis of microbial communities using culture-dependent and culture-independent approaches in an anaerobic/aerobic SBR reactor. J Microbiol 44, 155-161.

Smibert, R. M. \& Krieg, N. R. (1994). Phenotypic characterization. In Methods for General and Molecular Bacteriology, pp. 607-654. Edited by P. Gerhardt. Washington, DC: American Society for Microbiology.

Tamaoka, J. \& Komagata, K. (1984). Determination of DNA base composition by reversed-phase high-performance liquid chromatography. FEMS Microbiol Lett 25, 125-128.

Thompson, J. D., Higgins, D. G. \& Gibson, T. J. (1994). CLUSTAL W: improving the sensitivity of progressive multiple sequence alignment through sequence weighting, position-specific gap penalties and weight matrix choice. Nucleic Acids Res 22, 4673-4680.

Yi, H. \& Chun, J. (2004a). Hongiella mannitolivorans gen. nov., sp. nov., Hongiella halophila sp. nov. and Hongiella ornithinivorans sp. nov., isolated from tidal flat sediment. Int J Syst Evol Microbiol 54, 157162.

Yi, H. \& Chun, J. (2004b). Nocardioides ganghwensis sp. nov., isolated from tidal flat sediment. Int J Syst Evol Microbiol 54, 1295-1299.

Yi, H. \& Chun, J. (2004c). Nocardioides aestuarii sp. nov., isolated from tidal flat sediment. Int J Syst Evol Microbiol 54, 2151-2154.

Yoon, J. H., Kang, S. J., Jung, Y. T. \& Oh, T. K. (2008). Aestuariicola saemankumensis gen. nov., sp. nov., a member of the family Flavobacteriaceae, isolated from tidal flat sediment. Int J Syst Evol Microbiol 58, 2126-2131.

Yoon, J. H., Kang, S. J., Lee, J. S. \& Oh, T. K. (2009). Lutimaribacter saemankumensis gen. nov., sp. nov., isolated from a tidal flat of the Yellow Sea. Int J Syst Evol Microbiol 59, 48-52. 